\title{
Sustainable Dimensional Status Analysis in Dragon Fruits Agribusiness Development in Banyuwangi
}

\author{
Wahyu Widya Ningsih $^{1^{*}}$, Ridwan Iskandar ${ }^{2 *}$, K Kasutjianingati $^{3}$ \\ 1, 2, 3 Agribusiness Postgraduate Department, Politeknik Negeri Jember, Indonesia \\ *Corresponding author.Email: wahyuwidya453@gmail.com, ridwan.iskandar@polije.ac.id
}

\begin{abstract}
Dragon fruit is one of the leading commodities that has been able to provide high commercial profits and prospective to be developed. This research aimed to analyse the sustainability of the dragon fruit agribusiness development adopted in Banyuwangi regency. This research was conducted in two sub-districts namely Bangorejo and Pesanggaran located in Banyuwangi Regency. In addition, the research used Rap-dragon fruit through Multi-dimensional Scaling (MDS) to analyse sustainability into 33 attributes of 5 dimensions included ecological, economic, social, technological and institutional dimensions. Meanwhile, the result of the Multi-dimensional sustainability analysis of the Banyuwangi dragon fruit sustainability index was 57,50 included in the quite sustainable category. While the result of the sustainability index analysis for the five dimensions are 52,86 (ecology); 45,19 (economic); 57,13 (social); 70,24 (technology); 56,22 (institution). The sustainability of dragon fruit in each dimension has a different sustainability index so that different policies are needed to evaluate the sustainability of dragon fruit in Banyuwangi.
\end{abstract}

Keywords: Dragon Fruit, Multi-dimensional Scaling, Sustainability.

\section{INTRODUCTION}

One of the efforts made in the development and development of the region is the development of the agricultural sector specifically for superior commodities. Based on data from the 2016-2020 Banyuwangi Regency PDRB, the growth of PDRB by field based on constant prices of all sectors, namely the agricultural sector, had the highest contribution of $28.05 \%$. The superior products of Banyuwangi agriculture are rice, corn, soybeans, coffee, mangosteen fruit, oranges and dragon fruit. Since it began to be developed in Banyuwangi Regency, the dragon fruit's flagship commodity has always shown a positive widespread growth rate of harvest. Dragon fruit is one of the horticultural commodities that have not long been known, cultivated, and cultivated in Indonesia [1]. Here is the extensive data of dragon fruit commodity harvest in 2015-2019 in Banyuwangi Regency in 2015 harvest area of $1,213.30 \mathrm{Ha}$, in 2016 with a harvest area of $1,275.50 \mathrm{Ha}$, in 2017 the harvest area of $1,290 \mathrm{Ha}$, in 2018 the harvest area of $1,322 \mathrm{Ha}$ and in 2019 the harvest area of 1,362 $\mathrm{Ha}$ [2]. The center of the dragon fruit production area in Banyuwangi is located in
Bangorejo, Purwoharjo, Pesanggaran, Siliragung, Muncar and Tegaldlimo districts.

Dragon fruit productivity increased from previous years, but decreased in 2019, reaching $262 \mathrm{Kw} / \mathrm{Ha}$ with a land area of 1,362 ha, it shows that the condition of dragon fruit productivity is fluctuating. Dragon fruit cultivation requires optimal care and management of plants, such as binding, fertilization, irrigation, pruning, pest control and disease.

Problems that are often experienced by farmers in the development of dragon fruit agribusiness are the limitations of maintenance management and the weak institutional system of recipients of dragon fruit agribusiness output. The lack of information caused by the absence of communication networks with agribusiness actors causes the selling price of farmers' products to be low such as, the price of dragon fruit in 2018 range of Rp. 1,500 / Kg but there are still collectors who buy, but for the harvest season in 2019 the price of dragon fruit ranges from Rp. 1,000-Rp. $2,000 / \mathrm{Kg}$. This condition causes the helplessness of farmers in determining the selling price, so the price of dragon fruit in 2018-2019 is relatively variable. Such conditions result in a less targeted development strategy 
because it requires the support of all parties, including farmers and related institutions to increase the effectiveness of dragon fruit agribusiness development. The absence of the participation of farmers and related institutions resulted in the sustainability of the development process did not work as it should.

Efforts are needed to improve sustainability and improvement of development strategies on dragon fruit agribusiness using the Multi-Dimensional Scaling (MDS) method. The effort required in the MDS method is to identify the sustainability aspects of dragon fruit agribusiness development. The principles of MultiDimensional Scaling (MDS) analysis are designed to assess the sustainability status of a system on a "bad" to "good" sustainability scale. This assessment is done with the scoring approach of the attributes [3].

This article examines the sustainability status of dragon fruit agribusiness in Banyuwangi Regency. The sustainability status of dragon fruit agribusiness is analyzed to be a reference in formulating specific policy strategies in the development of these commodities in the future so that the formulated strategies can be implemented.

\section{RESEARCH METHODS}

\subsection{Location and Time of Research}

This research was carried out in two sub-districts in Banyuwangi, namely Bangorejo District (Kebondalem and Temurejo Village) and Peanggaran District (Sumberagung village and Sumbermulyo). Research time was conducted in March-August 2021.

\subsection{Population and Research Samples}

The population in this study was dragon fruit farmers, dragon fruit collectors, dragon fruit traders, dragon fruit buyers, field extensionists, and the Department of Agriculture and Food Banyuwangi regency. The sample sizes in the study were between 30 to 500. [4]. The farmer sampling method is carried out by the phased cluster sample method (Multistage Stratified Cluster Sampling) to gather information and data from respondents. Dragon fruit farmers as many as 30people, dragon fruit collectors as many as 4 people, dragon fruit traders as many as 4 people, and dragon fruit buyers as many as 4 people.

The interest in identifying factors/attributes of the five dimensions in dragon fruit agribusiness in Banyuwangi Regency was selected by 6 expert respondents consisting of 2 field extension sections each in Bangorejo and Pesanggaran districts, and 1 dragon fruit farmer, and 1 head of the Department of Agriculture and Food, Banyuwangi regency.

\subsection{Data Collection Techniques and Analytical Methods}

The methods used are observation, interview, and documentation. Sustainability analysis is carried out with a Multi-Dimensional Scaling (MDS) approach called the approach of the method RAP-FARM (The Rapid Appraisal of the Status of Farming) modified from the program Rapfish (Rapid Assessment Techniques for Fisheries) developed by Fisheries Center, University of British Columbia [3].

\begin{tabular}{|l|l|}
\hline Index Value & \multicolumn{1}{|c|}{ Category } \\
\hline $0.00-25.00$ & Bad: Unsustainable \\
\hline $25.01-50.00$ & Less: Less Sustainable \\
\hline $50.01-75.00$ & Enough: Fairly Sustainable \\
\hline $75.01-100.00$ & Good: Very Sustainable \\
\hline
\end{tabular}

Table 1. Sustainability Index and Status

Source: Fauzi, 2019

There are stages in sustainability analysis: (1) determination of attributes of each dimension, (2) assessment of attributes of each dimension, and (3) assessment of index and sustainability status consisting of ordination analysis, leverage analysis, monte carlo, and kite diagram.

\section{RESULTS AND DISCUSSIONS}

\subsection{Sustainability Status and Dominant Attributes in Each Dimension}

\subsubsection{Ecological Dimensions}

The status of sustainability and the dominant attributes affecting the ecological dimension can be seen in figure 1. The results of MDS analysis with RapDragon Fruit, known the value of sustainability index of ecological dimensions of dragon fruit agribusiness in Banyuwangi Regency is 52.86. This value indicates that the sustainability status of dragon fruit agribusiness on a scale of $50.01-75.00$ so that it is categorized as Quite Sustainable. Factors that affect the ecological dimensions that need to be considered are irrigation networks with a value of 7.09. 


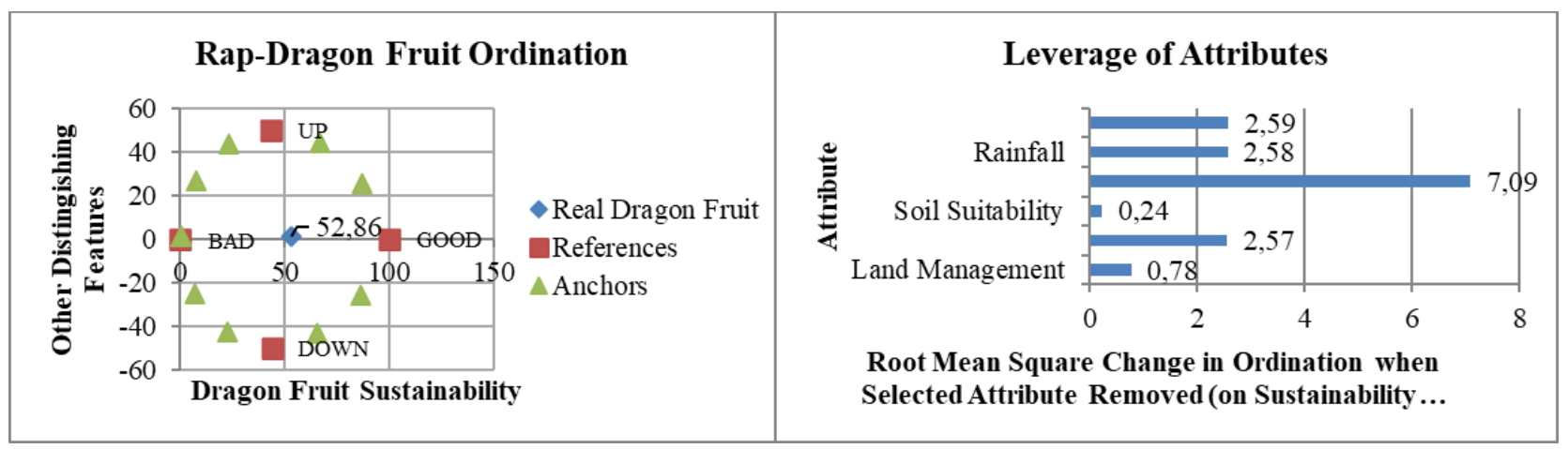

Figure 1 Sustainability Status and Dominant Attributes in the Ecological Dimension

\subsubsection{Economic Dimensions}

Sustainability status and dominant attributes affecting the economic dimension can be seen in figure 2. The results of MDS analysis with Rap-Dragon Fruit, show that the sustainability index value of the economic dimension of dragon fruit agribusiness in Banyuwangi Regency is 45.19. This value indicates that the

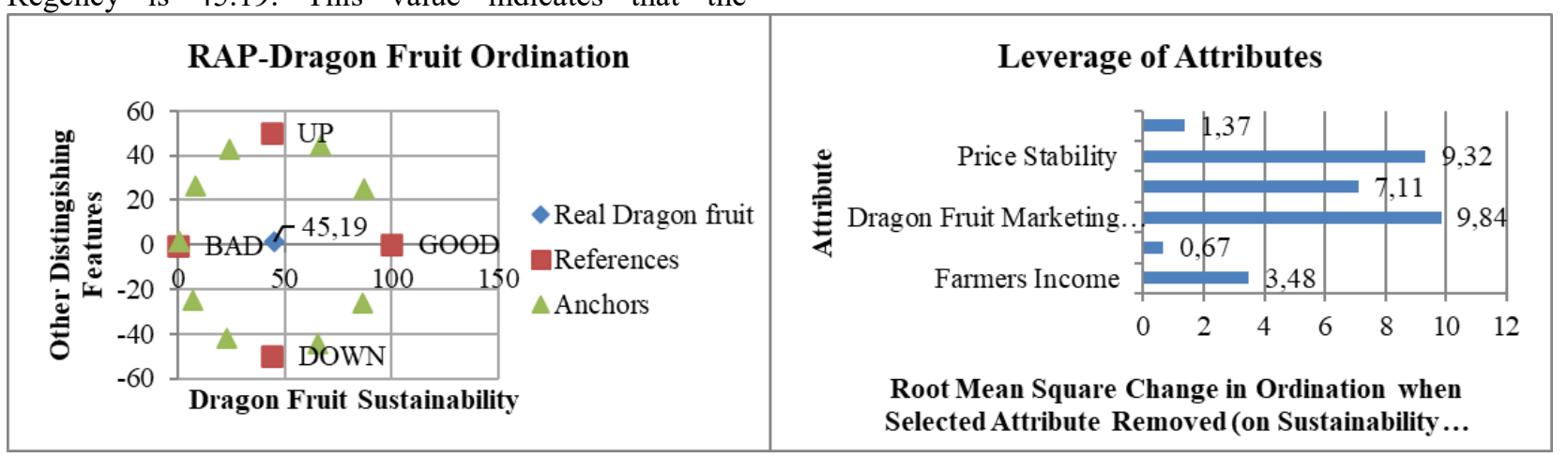

Figure 2 Sustainability Status and Dominant Attributes in the Economic Dimension

\subsubsection{Social Dimension}

Sustainability status and dominant attributes affecting the social dimension can be seen in figure 3 . Result MDS analysis with Rap-Dragon Fruit, known the value of the sustainability index of the social dimension of dragon fruit agribusiness in Banyuwangi Regency is 57.13. This value indicates that the sustainability status sustainability status of dragon fruit agribusiness on a scale of $25.01-50.00$ so it is categorized as Less Sustainable. Factors that affect the economic dimensions that really need to be considered are marketing reach with a value of 9.84 .

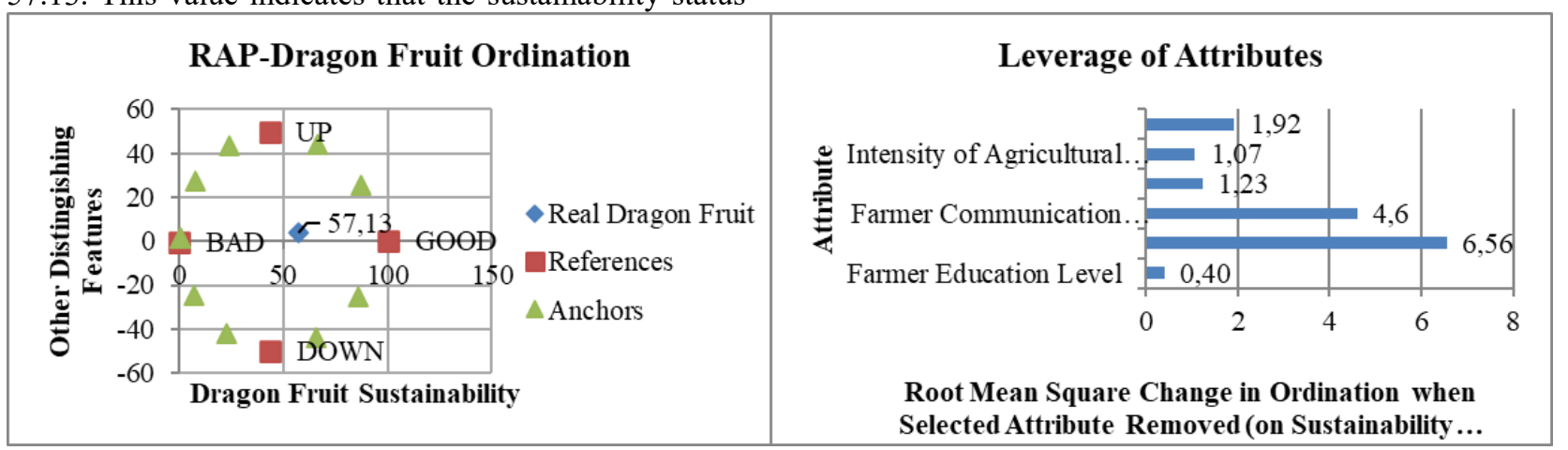

Figure 3 Sustainability Status and Dominant Attributes in the Social Dimension
3.1.4. Technological Dimensions
The status of sustainability and the dominant attributes affecting the technological dimension can be 
seen in figure 4. From the results of MDS analysis with Rap-Dragon Fruit, it is known that the sustainability index value of dragon fruit agribusiness technology dimensions in Banyuwangi Regency is 70.24. This value indicates that the sustainability status of dragon fruit agribusiness on a scale of $50.01-75.00$ so that it is categorized as Quite Sustainable. Factors that affect the technological dimensions that need to be considered are farmers' responses to new technologies with a value of 6.36 .

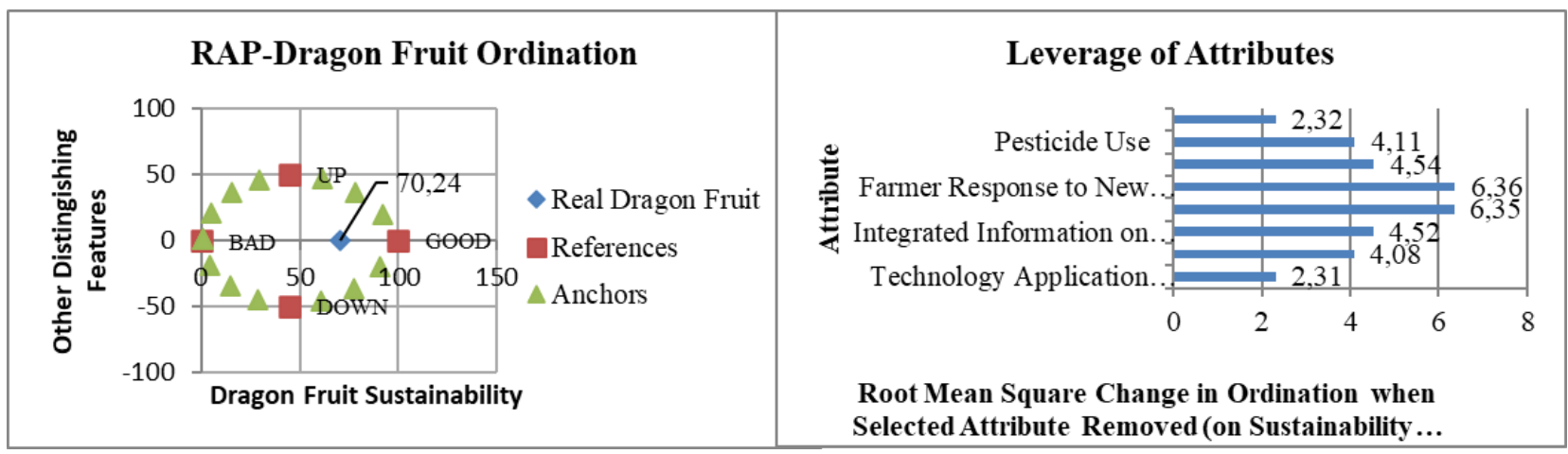

Figure 4 Sustainability Status and Dominant Attributes in the Technological Dimension

\subsubsection{Institutional Dimensions}

Sustainability status and dominant attributes affecting the institutional dimension can be seen in figure 5. The results of MDS analysis with Rap-Dragon Fruit, known the value of the sustainability index of the institutional dimension of dragon fruit agribusiness in Banyuwangi Regency is 56.22. This value indicates that

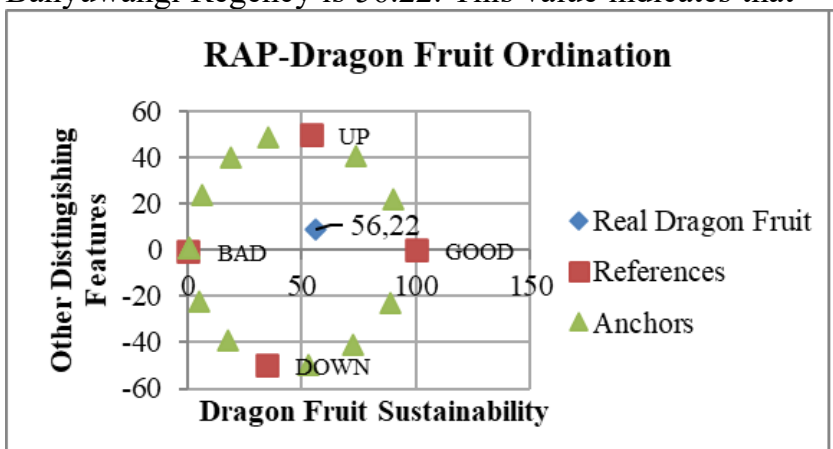

the sustainability status of dragon fruit agribusiness on a scale of 50.01 - 75.00 so that it is categorized as Quite Sustainable. Factors that affect the institutional dimensions that need to be considered are agricultural extension centers with a value of 5.57 .

Figure 5 Sustainability Status and Dominant Attributes in the Institutional Dimension

A Diagram of fish bones on the sustainability of dragon fruit agribusiness in Banyuwangi Regency can be seen in figure 6 . The fishbone diagram illustrates the sustainability of agribusiness because of 5 dimensions including ecological dimensions (irrigation networks and soil fertility rates), economic dimensions (marketing reach and price stability), social dimensions (land ownership status and intensity of farmer communication), technology dimensions (farmers' response to new technologies and standardization of dragon fruit quality) and institutional dimensions (agricultural extension hall and availability of capital institutions). 


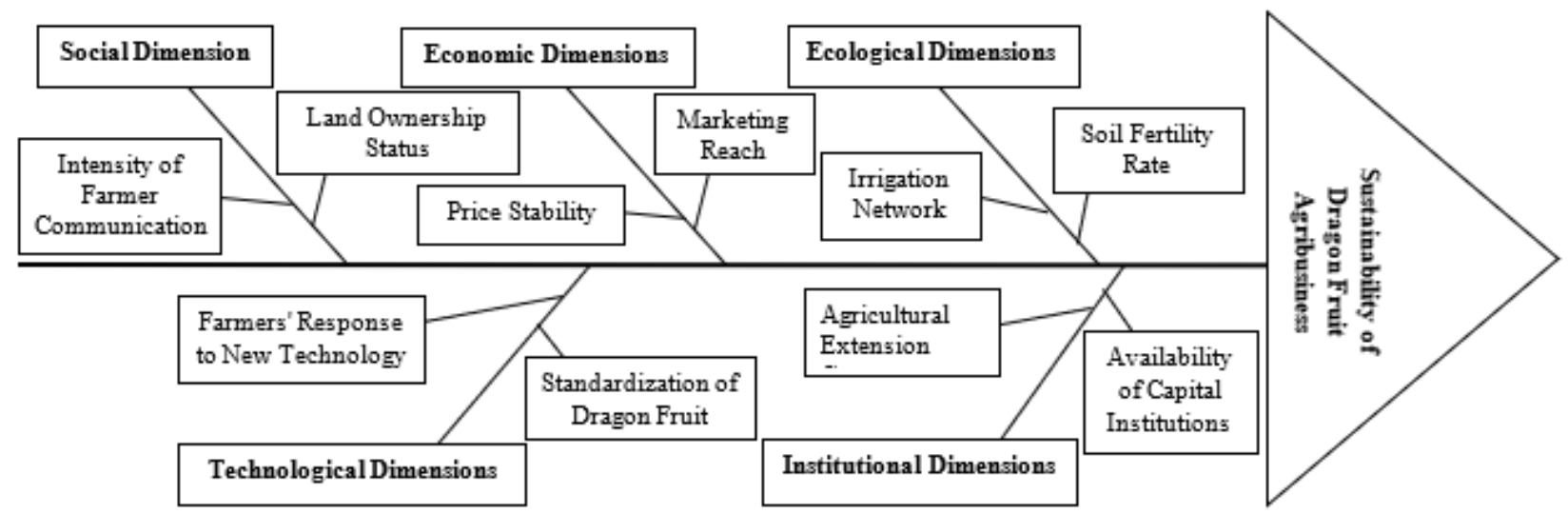

Figure 6 Dragon Fruit Agribusiness Sustainability Fish Bone Diagram

\subsection{Kite Diagram}

sustainable.

The value of the agribusiness sustainability index of dragon fruit in each dimension can be seen in the kite diagram in figure 7 and table 2. Existing conditions in ecological, economic, social, technological and institutional dimensions show a value of $57.50 \%$ with fairly sustainable conditions. Moderate conditions (improvement of moderate conditions) can increase the sustainability index to $72.52 \%$ or moderately

Table 2. Index Values and Sustainability Status Exist, Moderate and Optimistic

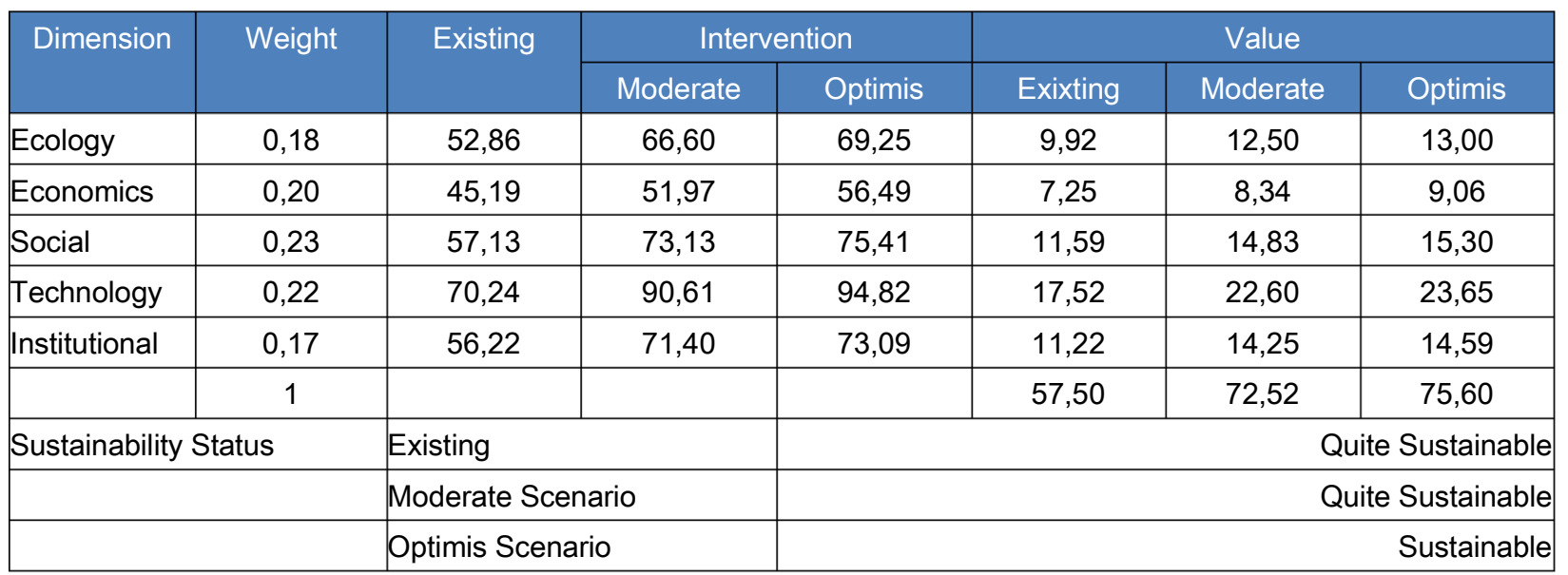

Source: Processed data, 2021

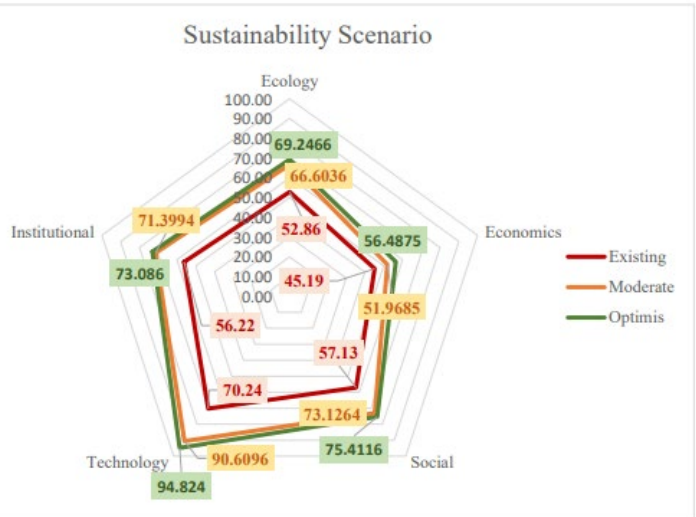


Figure 7 Dragon Fruit Agribusiness Kite Diagram in Banyuwangi Regency ecological dimension are: a) irrigation networks; and b) soil fertility rate. Priority attributes in the economic dimension are: a) marketing reach; and b) price stability.

Table 3. Difference in Value of Sustainability Index Multi Dimensional Scaling Analysis (MDS) with Monte Carlo Analysis 95\% Confidence Interval

\begin{tabular}{|l|c|c|c}
\hline \multirow{2}{*}{ Sustainability Dimension } & \multicolumn{2}{|c|}{ Sustainability Index Value (\%) } & \multicolumn{2}{c}{ Difference } \\
\cline { 2 - 4 } & MDS & Monte Carlo & 0,32 \\
\hline Ecology & 52,86 & 52,54 & 0,49 \\
\hline Economics & 45,19 & 44,70 & 0,51 \\
\hline Social & 57,13 & 56,62 & 0,56 \\
\hline Technology & 70,24 & 69,68 & 0,54 \\
\hline Institutional & 56,22 & 55,68 & 0 \\
\hline
\end{tabular}

Source: Processed data, 2021

While the optimistic scenario (improvement in maximum conditions) can increase the sustainability index to $75.60 \%$ to make the condition of the development of dragon fruit agribusiness in Banyuwangi Regency in good condition or sustainable.

\subsection{Monte Carlo}

Looking at the error rate in the Rap-Dragon Fruit analysis, a Monte Carlo analysis was conducted. This analysis was conducted at a $95 \%$ confidence level. The difference in values of the Multi Dimensional Scaling Analysis Sustainability Index (MDS) with the Monte Carlo analysis is presented in table 3.

Monte Carlo Analysis, showing that errors in Multi Dimensional Scaling (MDS) analysis are no more real than Monte Carlo analysis because the difference is less than 1. It is known that the value of the Multi Dimensional Scaling sustainability index (MDS) and Monte Carlo each dimension on the development of dragon fruit agribusiness in Banyuwangi Regency has a difference of less than 1 .

\section{CONCLUSION}

Dragon fruit agribusiness in Banyuwangi Regency has sustainability with criteria of "quite sustainable" in view of 5 dimensions of sustainability, namely ecological dimension, economic dimension, social dimension, technological dimension, and institutional dimension of multi-dimensional scaling (MDS) analysis results. The dimension that has the highest index and sustainability status is the technological dimension of 70.24; while the other 4 dimensions are 52.86 (ecology); 45.19 (economy); 57.13 (social); 56.22 (institutional). Each dimension has 2 priority attributes that are further used to design the policy scenario of sustainable development of dragon fruit agribusiness in Banyuwangi Regency. Priority attributes on the
Priority attributes on the social dimension are: a) land ownership status; and b) the intensity of the farmer's communication. Priority attributes on the technological dimension are: a) the farmer's response to new technologies; and b) standardize the quality of dragon fruit. Priority attributes in the institutional dimension are: a) agricultural extension hall; and b) availability of capital institutions.

\section{REFERENCES}

[1] Kristriandiny, O. and S. Susanto, Budidaya Buah Naga Puth (Hylocereus Undatus) di Sleman, in: Yogyakarta: Panen dan Pascapanen. Jurnal Agrohorti, vol. 4(1), 2016, pp. 1-8. DOI: https://journal.ipb.ac.id/index.php/bulagron/article/ view/14993

[2] Dinas Pertanian and Pangan Kabupaten Banyuwangi, Sentra Kawasan Hortikultura, in: Banyuwangi, Dinas Pertanian dan Pangan Banyuwangi, 2019.

[3] Fauzi, Akhmad, Teknik Analisis Keberlanjutan, in: Jakarta, PT Gramedia Pustaka Utama, 2019.

[4] Sugiyono, Metode Penelitian Kuantitatif, Kualitatif, dan R \& D, Cetakan Pertama, in: Bandung, Aflabeta, 2016. 